\title{
ANAK DIDIK PERSPEKTIF NATIVISME, EMPIRISME, DAN KONVERGENSI
}

\author{
Sitti Nadirah \\ IAIN Datokarama Palu \\ Sekolah Tinggi Agama Islam Negeri (STAIN) \\ Datokarama Palu Jalan Diponegoro No. 23 \\ Email: humas@stain_palu.ac.id
}

\begin{abstract}
Abstrak:
Anak didik merupakan individu yang mengalami pertumbuhan dan perkembangan yang memerlukan bimbingan orang dewasa. Nativisme berpendapat bahwa perkembangan manusia ditentukan oleh potensi sejak lahir dan lingkungan tak dapat merubahnya. Sedangkan aliran Empirisme menjelaskan bahwa manusia sangat dipengaruhi dan ditentukan oleh lingkungan alam sekitarnya. Aliran Konvergensi berpendapat bahwa pembawaan dan lingkungan kedua-duanya sangat menentukan perkembangan manusia. Dalam padangan al-Qur'an fitrah manusia diberikan Allah sebagai bawaan dari lahir tetap memerlukan proses interaksi dari lingkungan sekitar secara dinamis.
\end{abstract}

\begin{abstract}
:
The students are individuals who experience growth and development and require adult guidance. Nativism argues that human development is determined by the potential from birth and cannot be changed by environment; However, Empiricism explained that the human was heavily influenced and determined by their environment. Different from Nativism and Empiricism, Convergence argues that nature and nurture (environment) are both crucial for human development. In the Qur'an perspective, human is born with their nature (fitrah) as a potential given by Allah, but still requires the interaction with their environment dynamically.
\end{abstract}

Kata kunci:

Anak Didik, Nativisme, Empirisme, Konvergensi, Fitrah

SEJAK manusia menghendaki kemajuan dalam kehidupan, maka sejak itu timbul gagasan untuk melakukan pengalihan, pelestarian dan pengembangan kebudayaan melalui pendidikan. Oleh karena itu, pendidikan di dalam masyarakat senantiasa menjadi perhatian utama dalam rangka memajukan kehidupan generasi yang sejalan dengan tuntutan, perkembangan dan kemajuan masyarakat dari zaman ke zaman.

Manusia adalah subyek dan objek pendidikan, manusia dewasa yang berkebudayaan adalah subyek pendidikan dalam arti yang bertanggung jawab menyelenggarakan pendidikan. Mereka berkewajiban secara moral atas perkembangan pribadi anak-anak mereka, generasi penerus mereka, manusia dewasa yang berkebudayaan terutama yang berpotensi keguruan (pendidikan) bertanggung jawab formal untuk melaksanakan misi pendidikan sesuai dengan tujuan dan nilai-nilai yang dikehendaki oleh masyarakat bangsa itu. ${ }^{1}$ 
Dalam belajar mengajar, guru dan murid memegang peranan penting. Murid atau anak didik adalah pribadi yang unik yang mempunyai potensi dan mengalami proses berkembang. Dalam proses berkembang itu anak atau murid membutuhkan bantuan yang sifat dan coraknya tidak ditentukan oleh guru tetapi oleh anak itu sendiri, dalam suatu kehidupan bersama dengan individu-individu yang lain. ${ }^{2}$

Dalam pendidikan Islam, peserta didik dimaknai sebagai manusia yang sepanjang hidupnya selalu berada dalam perkembangan. Perkembangan yang dimaksud dalam hal ini bukan hanya pada segi eksternal melainkan juga perkembangan internal. Jadi, anak-anak yang sedang dalam pengasuhan dan pengasihan orang tuanya, dan juga pada anak-anak dalam usia sekolah. Tidaklah cukup untuk membantu perkembangan anak-didik, tetapi juga kepada seluruh komponen penunjang terlaksananya pendidikan.

Dari latar belakang di atas penulis mencoba mengkaji dan menganalisis persoalan-persoalan yang terkait dengan proses pembentukan anak didik dengan merumuskan suatu permasalahan sebagai berikut:

1. Bagaimana konsepsi tentang anak didik?

2. Bagaimana pandangan aliran nativisme, empirisme, dan konvergensi tentang anak didik/peserta didik?

3. Bagaimana eksistensi fitrah sebagai potensi dasar peserta didik (anak didik)?

\section{PENGERTIAN PESERTA DIDIK/ANAK DIDIK}

Pendidikan ibarat uang logam, selalu memiliki 2 (dua) sisi. Satu pihak bertugas mengajar, sedangkan pihak lain tugasnya belajar. Satu sisi memberi, sisi lain menerima. Anak didik merupakan salah satu dari dua sisi tersebut yang memiliki tugas menerima konsep pendidikan agar dalam dirinya terbentuk insan muslim yang tahu akan Tuhan dan agamanya. Demikian pula ia harus memiliki akhlak al-Qur'an, bersikap dan bertindak sesuai dengan kaidah al-Qur'an, berpikir dan berbuat demi kepentingan umat. ${ }^{3}$

Anak didik dalam pendidikan Islam adalah anak yang sedang tumbuh dan berkembang baik secara fisik dan psikologis untuk mencapai tujuan pendidikan melalui lembaga pendidikan. Manusia yang belum dewasa (anak didik), dalam proses perkembangan pribadinya, baik menuju pembudayaan maupun proses kematangan dan integritas, adalah objek pendidikan. Artinya mereka adalah sasaran atau "bahan" yang dibina. ${ }^{4}$

Pengertian tersebut memberikan arti bahwa anak didik/peserta didik adalah anak yang belum dewasa, yang dalam artian mencerminkan keinginan untuk tumbuh dan berkembang dari orang lain untuk menjadi dewasa. Anak kandung adalah anak didik keluarga, murid/siswa adalah anak didik di sekolah, anak-anak penduduk adalah anak didik masyarakat di sekitarnya, dan anak umat beragama adalah menjadi anak didik kerohanian agama. Ini menandakan bahwa keseluruhan anak tersebut sangat tergantung pada orang dewasa yang harus memahaminya sebagai orang yang sangat membutuhkan bantuan untuk tumbuh dan berkembang sesuai dengan pengertian dan tujuan pendidikan Islam. 


\section{PANDANGAN ALIRAN NATIVISME, EMPIRISME, DAN KONVERGENSI TENTANG PEMBAWAAN ANAK DIDIK/PESERTA DIDIK}

Pembawaan adalah seluruh potensi yang terdapat pada suatu individu dan selama masa perkembangannya benar-benar dapat diwujudkan (direalisasikan). ${ }^{5}$ Dapat dikatakan bahwa anak atau manusia sejak dilahirkan telah mempunyai potensi atau kesanggupan untuk dapat berjalan, potensi untuk dapat berkata-kata dan potensi-potensi lain. Potensi-potensi itu tidak begitu saja dapat direalisasikan atau dengan begitu saja dapat menyatakan diri dalam perwujudannya. Untuk dapat diwujudkan sehingga kelihatan dengan nyata, potensi-potensi tersebut harus mengalami perkembangan serta membutuhkan latihan-latihan.

Masalah pembawaan memerlukan penjelasan dan penafsiran untuk memahami secara mendalam. Para ahli psikologi, ahli biologi dan ahli-ahli lainnya telah berusaha selama bertahun-tahun lamanya untuk memikirkan dan berusaha mencari jawaban atas pertanyaan tentang perkembangan manusia itu, apakah tergantung kepada pembawaan (keturunan) ataukah kepada lingkungan. Pencarian melalui berpikir tersebut melahirkan teori yang berani mempresentasekan hasil temuannya kepada masyarakat dunia walaupun masih di luar konsep al-Qur'an dan sunnah.

Untuk lebih jelasnya penulis akan memaparkan pandangan para ilmuan mengenai pembawaan anak didik itu:

\section{Aliran Nativisme}

Nativisme berasal dari kata native artinya asli atau asal. ${ }^{6}$ Aliran ini hampir senada dengan Naturalisme. Nativisme berpendapat bahwa sejak lahir anak telah memiliki/membawa sifat-sifat dan dasar-dasar tertentu, yang bersifat pembawaan atau keturunan. Sifat-sifat dan dasar-dasar tertentu yang bersifat keturunan (herediter) inilah yang menentukan pertumbuhan dan perkembangan anak sepenuhnya. Sedangkan pendidikan dan lingkungan boleh dikatakan tidak berarti, kecuali hanya sebagai wadah dan memberikan rangsangan saja. ${ }^{7}$ Dalam ilmu pendidikan, pandangan tersebut dikenal dengan pesimisme paedagogis. Tokoh utama aliran ini ialah Schopenhauer. Dalam artinya yang terbatas, juga dapat dimasukkan dalam golongan Plato, Descartes, Lomborso, dan pengikut-pengikutnya yang lain.

\section{Aliran Empirisme}

Tokoh utama aliran ini ialah John Locke. Ia berpendapat bahwa perkembangan anak menjadi manusia dewasa itu sama sekali ditentukan oleh lingkungannya atau oleh pendidikan dan pengalaman yang diterimanya sejak kecil. Manusia-manusia dapat dididik apa saja (ke arah yang baik dan ke arah yang buruk) menurut kehendak lingkungan atau pendidikan. Dalam hal ini, alamlah yang membentuknya. Dalam pendidikan, pendapat kaum empiris ini terkenal dengan nama optimisme paedagogis. ${ }^{8}$

\section{Aliran Konvergensi}

Aliran ini dimunculkan oleh ahli ilmu jiwa bangsa Jerman, William Stern. Ia mengatakan bahwa pembawaan dan lingkungan kedua-duanya menentukan perkembangan manusia. ${ }^{9}$ 
Dengan adanya pendapat ini, dapat dikatakan bahwa persoalan tentang pembawaan dan lingkungan itu sudah selesai. Dalam hukum konvergensi ini, masih terdapat dua aliran, yaitu aliran yang lebih menekankan kepada pengaruh pembawaan daripada pengaruh lingkungan dan yang sebaliknya, lebih menekankan lingkungan atau pendidikan. Sementara itu, banyak yang belum puas atas jawaban dari aliran konvergensi yang mengatakan bahwa perkembangan manusia itu ditentukan dari dua factor: pembawaan dan lingkungan.

\section{FITRAH SEBAGAI POTENSI DASAR MANUSIA DALAM PERKEMBANGAN}

Rasulullah saw. telah memberikan isyarat bahwa manusia sejak lahir telah membawa potensi untuk dikembangkan. Isyarat ini dapat dilihat pada sabdanya yang diriwayatkan dari Abu Hurairah sebagai berikut:

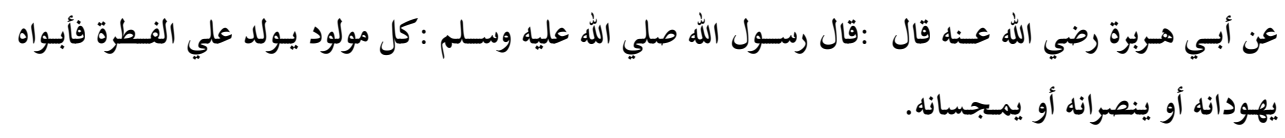

Manusia itu dilahirkan dengan fitrah (tabiat atau potensi yang suci dan baik), hanya ibu bapak (alam sekitar)nyalah menyebabkan ia menjadi Yahudi, Majuzi atau menjadi Nasrani. (H.R. Muslim). ${ }^{10}$

Hadis di atas menekankan bahwa fitrah yang dibawa sejak lahir oleh anak itu sangat besar dipengaruhi oleh lingkungan. Fitrah itu sendiri tidak akan berkembang tanpa dipengaruhi kondisi lingkungan sekitar yang mungkin dapat dimodifikasikan atau dapat diubah secara drastis menakala lingkungannya tidak memungkinkan menjadikannya lebih baik.11

Manusia dalam proses pendidikan adalah inti utama sehingga pendidikan sangat berkepentingan mengarahkan manusia kepada tujuan tertentu. Seorang pendidik akan terbantu dalam profesinya jika ia memahami dan memiliki gagasan yang jelas tentang fitrah dasar manusia. Pendidikan bakal mengalami kegagalan, kecuali dibangun atas konsep yang jelas mengenai fitrah manusia, sebab kenyataannya hasilhasil pendidikan banyak dipengaruhi konsep pendidik tentang fitrah manusia.

Bila direnungkan makna hadis yang dituliskan di atas, maka tampak bahwa yang dimaksud dengan "fitrah" manusia adalah kejadiannya sejak semula atau bawaan sejak lahirnya. Artinya, manusia sejak asal kejadiannya, membawa potensi beragama yang lurus dan dipahami oleh ulama sebagai tauhid. ${ }^{12}$ Selanjutnya menurut penulis, pengertian menjadi Yahudi, Nasrani, atau Majusi itu secara tekstual bermakna menyesatkan, sedangkan makna ibu bapak (alam sekitar) pada hadis tersebut kurang tepat. Fitrah yang asalnya suci sepatutunya berkembang ke arah yang baik dan benar. Untuk lebih memahami dengan jelas tentang fitrah sebagai pembawaan dasar rabbaniah, maka penulis memberi penajaman pada dua pembawaan sebagai berikut:

\section{Khalifah sebagai Sifat Dasar}

Manusia diciptakan oleh Allah swt. selain menjadi hamba-Nya, juga menjadi penguasa (khalifah) ${ }^{13}$ di atas bumi. Selaku hamba dan khalifah, manusia telah diberi 
kelengkapan kemampuan jasmaniah (fisiologis) dan rohaniah (mental psikologis) yang dapat ditumbuhkembangkan seoptimal mungkin sehingga menjadi alat yang berdaya guna dalam ikhtiar kemanusiaannya untuk melaksanakan tugas pokok kehidupannya di dunia. ${ }^{14}$

Tugas hidup manusia sebagai khalifah Allah di muka bumi ini dapat dipahami dari firman Allah dalam QS Fathir/35: 39.

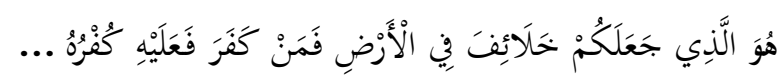

Dia-lah yang menjadikan kamu khalifah-khalifah di muka bumi. Barangsiapa yang kafir, maka (akibat) kekafirannya menimpa dirinya sendiri.

Demikianlah manusia menjadi khalifah Allah swt., di muka bumi, ia ditempatkan di bumi untuk mengelola apa yang ada di dalamnya dan untuk saling bantumembantu antara sesama manusia untuk memakmurkan bumi ini.

Manusia adalah makhluk yang termulia di antara makhluk-makhluk Allah yang lain sebagai mana dikemukakan dalam QS al-Isra/17: 70:

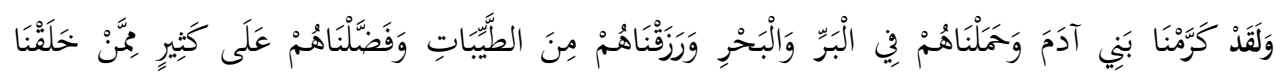

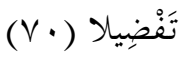

Dan sesungguhnya telah Kami muliakan anak-anak Adam, Kami angkat mereka di daratan dan di lautan. Kami beri mereka rezki dari yang baik-baik dan Kami lebihkan mereka dengan kelebihan yang sempurna atas kebanyakan makhluk yang telah Kami ciptakan.

Manusia dijadikan oleh Allah dalam sebaik-baik bentuk/kejadian, baik fisik maupun psikisnya. Firman Allah dalam QS al-Tiin/95: 4:

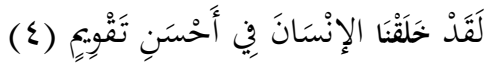

Sesungguhnya Kami telah menciptakan manusia dalam bentuk yang sebaik-baiknya.

Manusia dilengkapi dengan berbagai alat potensial dan potensi-potensi dasar (fitrah) yang dapat dikembangkan dan diaktualisasikan seoptimal mungkin melalui proses pendidikan. Karena itulah, maka sudah selayaknya manusia menyandang tugas sebagai khalifah Allah di muka bumi. ${ }^{15}$ Manusia harus bertanggung jawab dengan bekerja dan memelihara alam semesta ini sebagai suatu potensi dasar.

\section{Fitrah sebagai Potensi Dasar}

Belasan abad yang silam, Islam telah hadir dengan memberikan konsep "fitrahnya", namun sampai sekarang menjadi catatan apakah makna fitrah itu? Para ahli dalam kalangan Islam mencoba memformulasikan makna fitrahnya dan tiap formulasi yang dihasilkan melalui kajian dan argumentasi yang kuat.

Al-Raghib al-Asfahani ketika menjelaskan makna fitrah dari segi bahasa, dia mengungkapkan kalimat fathara Allah al-khalq, yang maksudnya Allah mewujudkan 
sesuatu dan menciptakannya bentuk/keadaan kemampuan untuk melakukan perbuatan-perbuatan. ${ }^{16}$

Adapun fitrah disebutkan dalam QS al-Rum/30: 30

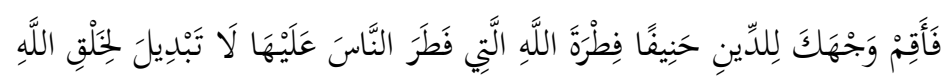

Maka hadapkanlah wajahmu dengan lurus kepada agama (Allah); (tetaplah atas) fitrah Allah yang telah menciptakan manusia menurut fitrah itu. ${ }^{17}$

Dalam hubungannya dengan konsepsi kependidikan Islam yang natives, faktor pembawaan diakui pula sebagai unsur pembentuk corak keagamaan dalam diri manusia. Hal ini digambarkan dalam kitab suci al-Qur'an tentang peristiwa Nabi Ibrahim yang orang tuanya menyembah berhala. Dengan kemampuan akal pikirannya yang mencari dan menyelidiki alam sekitar, akhirnya dapat menemukan Tuhannya yang benar sesuai dengan keislamannya. Sebaliknya, anak Nabi Nuh yang tidak mau mengikuti ayahnya naik ke atas perahu ketika banjir besar melanda dunia, ia tetap dalam status nonmuslim (kafir) walaupun ayahnya sebagai nabi yang Islam. ${ }^{18}$

Oleh karena itu, bilamana dipertanyakan mengapa manusia menjadi muslim dan menjadi nonmuslim, maka jawabannya dapat diberikan bahwa setiap diri manusia telah memiliki arah kecenderungan individual yang diperkuat oleh proses pendidikan atau diperlemah melalui pengalaman kependidikan dan pengaruh ekternal lainnya.

Informasi kitab suci al-Qur'an dan sabda Nabi, bila dianalisis secara situasional (menurut suasana kejadian tertentu) jelaslah menunjukkan bahwa faktor dasar dan faktor ajar selalu berdampingan dalam mendasari pertumbuhan atau perkembangan manusia. Konsepsi Islam dalam pendidikan bisa dikatakan beraliran Konvergensi ala William Stern yang berarti Islam mempertemukan pengaruh dasar dengan pengaruh ajar, pengaruh pembawaan, dan pendidikan menjadi suatu kekuatan terpadu yang berproses ke arah pembentukan kepribadian yang sempurna.

Maka jelaslah bahwa manusia dalam proses kependidikan menurut Islam tidak lain adalah manusia yang memerlukan tuntunan dan bimbingan yang tepat melalui proses kependidikan, sehingga terbentuklah dalam pribadinya suatu kemampuan mengaktualisasikan dirinya selaku sosok individual, dan sekaligus kemampuan memfungsikan dirinya selaku anggota masyarakat serta mendermabaktikan dirinya hanya kepada Khaliknya semata.

Untuk tujuan itulah manusia dijadikan oleh Tuhan dalam bentuk acuan yang paling baik sebagaimana firman-Nya dalam kitab suci al-Qur'an:

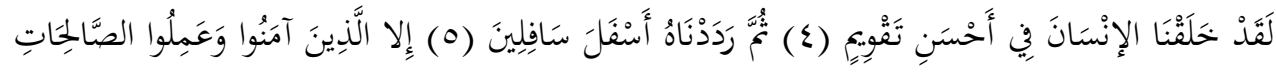

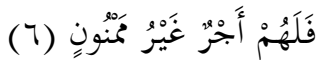

Sesungguhnya Kami telah menciptakan manusia dalam bentuk yang sebaik-baiknya. Kemudian Kami kembalikan dia ke tempat yang serendah-rendahnya (neraka), kecuali orang-orang yang beriman dan mengerjakan amal saleh; maka bagi mereka pahala yang tiada putus-putusnya. ${ }^{19}$ 
Bilamana manusia tidak mendapatkan pendidikan yang baik, dalam arti pada lingkup nilai-nilai islami maka ia akan mudah tergelincir ke derajat yang paling rendah. Jadi, faktor ikhtiarlah yang mengandung nilai pedagogis yang menentukan kedudukan atau martabat kemanusiaannya selaku hamba Allah yang secara individual dan sosial senantiasa membina hubungan dengan Allah dan hubungan dengan masyarakatnya.

\section{PENUTUP}

Mencermati uraian bahasan di atas, maka dapat disimpulkan sebagai berikut:

1. Anak didik/peserta didik dalam pendidikan Islam adalah anak yang belum dewasa yang sedang tumbuh dan berkembang secara fisik maupun psikologi berusaha untuk mencapai tujuannya, melalui bimbingan dan didikan dari orang dewasa baik secara lembaga maupun non lembaga yang secara sistematis dan berkelanjutan.

2. Faktor pembawaan anak didik/peserta didik ditinjau dari tiga aliran yaitu:

- Nativisme berpendapat bahwa segala perkembangan manusia itu telah ditentukan oleh potensi sejak lahir dan lingkungan tak dapat merubahnya.

- Empirisme berpendapat bahwa manusia menjadi dewasa sangat dipengaruhi dan ditentukan oleh lingkungan alam sekitarnya.

- Konvergensi berpendapat bahwa pembawaan dan lingkungan kedua-duanya sangat menentukan perkembangan manusia.

3. Fitrah manusia diberikan Allah sebagai bawaan dari lahir tetap memerlukan proses interaksi dari lingkungan sekitar secara dinamis.

Setelah memperhatikan hasil berdasarkan pembahasan, maka dikemukakan implikasi sebagai berikut:

1. Diharapkan para guru untuk senantiasa memperhatikan dan mengembangkan seluruh potensi peserta didik secara simultan dengan cara memadukan ketiga aliran perkembangan anak didik.

2. Disarankan kepada semua pihak dari pimpinan, pemerintah untuk mengadakan berbagai pelatihan dalam hal keguruan.

3. Disampaikan kepada guru agar dapat menjaga kode etik, menjalin hubungan baik dengan masyarakat, dalam hal ini orang tua siswa maupun pemerintah dalam rangka menjamin kestabilan perkembangan peserta didik.

\section{CATATAN AKHIR}

1. A. Rahman Getteng, Pendidikan Islam dalam Pembangunan, Ujung Pandang: Yayasan alAhkam, 1977, h. 11.

2. Zakiah Daradjat, Metodik Khusus Pengajaran Agama Islam, Cet. II; Jakarta: Bumi Aksara, 2001, h. 268.

3. Kamal Muhammad 'Isa, Manajemen Pendidikan Islam, Cet. I; Jakarta: Fikahati Aneska, 2004, h. 79.

4. A. Rahman Getteng, op cit., h. 11.

5. M. Ngalim Purwanto, Psikologi Pendidikan, Cet. XX; Bandung: PT. Remaja Rosdakarya, 2004, h. 21. 
6. Ahmad D. Marimba, Pengantar Filsafat Pendidikan, Cet. VIII; Bandung: PT. Al-Maarif, 1989, h. 35 .

7. Tadjab, Ilmu Jiwa Pendidikan, Cet. I; Surabaya: Karya Abditama, 1994, h. 20-21.

8. Lihat, Sumadi Suryabrata, Psikologi Pendidikan, Cet. XI; Jakarta: PT. Raja Grafindo Persada, 2002, h. 178, Lihat pula, Ngalim Purwanto, op. cit., h. 14-15.

9. Ngalim Purwanto, ibid., h. 15.

10. Al-Bukhari Al-Imam Abu 'Abdillah bin Ismail bin 1-Mughirah bin Bardizbah, Shahih alBukhary, Juz. III, Baerut: Dar Fikr. tt., h. 52.

11. Lihat Abdurrahman Saleh Abdullah, Teori-Teori Pendidikan Berdasarkan al-Qur'an, Cet. II; Jakarta: Rineka Cipta, 2004, h. 62.

12. Lihat M.Quraish Shihab, Membumikan al-Qur'an, Cet. XI; Bndung: Mizan, 2000, h. 284.

13. Kata khilafah berasal dari kata khalf (menggantikan, mengganti), atau kata khalaf (orang yang terdahulu). Sedangkan arti khalifah adalah menggantikan yang lain, adakalanya karena tidak adanya (tidak hadirnya) orang yang diganti, atau karena kematian orang yang diganti, misalnya Abu Bakar ditunjuk oleh umat Islam sebagai khalifah pengganti Nabi saw., yakni penerus dari perjuangan Nabi saw. dan pemimpin umat yang menggantikan Nabi saw setelah beliau wafat. Lihat, Muhaimin, Paradigma Pendidikan Islam, Cet. II; Bandung: PT. Remaja Rosdakarya, 2002, h. 22.

14. Muzayyin Arifin, Filsafat Pendidikan Islam, Cet. I; Jakarta: PT. Bumi Aksara, 2003, h. 141.

15. Muhaimin, op. cit., h. 22-23.

16. Ibid., h. 16.

17. Al-Qur'an dan Terjemahnya, Q.S. Ar-Ruum: 30.

18. Muzayyin Arifin, op. cit., h. 146.

19. Q.S. At-Tiin : 4-6

\section{DAFTAR PUSTAKA}

Al-Qur'an dan Terjemahnya.

Arifin, Muzayyin. Filsafat Pendidikan Islam. Cet. I; Jakarta: PT. Bumi Aksara, 2003.

D. Marimba, Ahmad. Pengantar Filsafat Pendidikan. Cet. VIII; Bandung: PT. Al-Maarif, 1989.

Daradjat, Zakiah. Metodik Khusus Pengajaran Agama Islam. Cet. II; Jakarta: Bumi Aksara, 2001.

Getteng, A. Rahman. Pendidikan Islam Dalam Pembangunan. Ujung Pandang: Yayasan alAhkam, 1977.

Muhaimin. Paradigma Pendidikan Islam. Cet. II; Bandung: PT. Remaja Rosdakarya, 2002.

Muhammad ‘Isa, Kamal. Manajemen Pendidikan Islam. Cet. I; Jakarta: Fikahati Aneska, 2004.

Purwanto, M. Ngalim. Psikologi Pendidikan. Cet. XX; Bandung: PT. Remaja Rosdakarya, 2004.

Abdullah, Abdurrahman Saleh. Teori-Teori Pendidikan Berdasarkan al-Qur'an. Cet. II; Jakarta: Rineka Cipta, 2004.

Shihab, M. Quraish. Membumikan al-Qur'an. Cet. XI; Bndung: Mizan, 2000.

Suryabrata, Sumadi. Psikologi Pendidikan. Cet. XI; Jakarta: PT. Raja Grafindo Persada, 2002.

Tadjab. Ilmu Jiwa Pendidikan. Cet. I; Surabaya: Karya Abditama, 1994. 